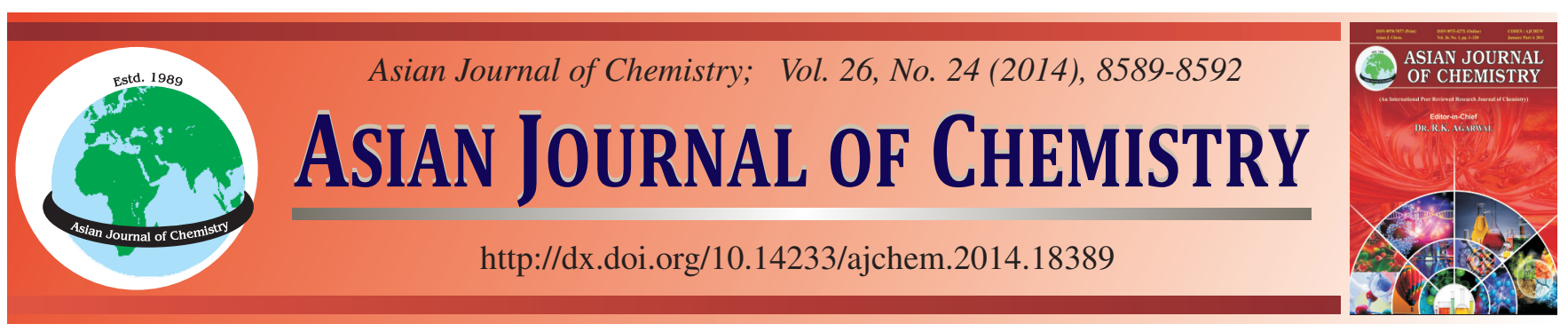

\title{
Modeling and Optimization of Adsorption and Removal of Cd(II) from Aqueous Solution by Phosphogypsum
}

\author{
D. ChafiK*, R. Bchitou and A. Bouhaouss
}

Department of Chemistry, Nanostructures Laboratory, Process Engineering and Environment, Faculty of Sciences, University Mohammed V-Agdal, Rabat, Morocco

*Corresponding author: E-mail: chafik-2005@ hotmail.com

\begin{abstract}
The aim of this work is the modeling and the optimization of the adsorption and the removal of cadmium by the phosphogypsum from aqueous solution. Generally, the attacks of the phosphate rock react with sulfuric acid to produce a major product phosphoric acid and phosphogypsum as a by product. This latter could be used for removing inorganic heavy metal impurities such as cadmium from aqueous solutions. We have applied two techniques for the modeling and the optimization of the removal of cadmium: First, we have used the technique of isotherms of Langmuir, Freundlich and Temkin in order to evaluate the metal quantity adsorbed. Second, we adopted the technique of Box-Behnken design experiments. The determining factors for the processes are the contact time, the concentration of $\mathrm{Cd}(\mathrm{II})$ and the phosphogypsum. The optimum concentration of $\mathrm{Cd}(\mathrm{II})$ adsorbed and phosphogypsum is $125 \mathrm{mg} / \mathrm{L}$ and $15 \mathrm{~g} / \mathrm{L}$, respectively at $\mathrm{pH}=5,84$ and $\mathrm{T}=22^{\circ} \mathrm{C}$.
\end{abstract}

Keywords: Cadmium, Phosphogypsum, Adsorption, Removal, Aqueous solutions and Box-Behnken design experiments.

\section{INTRODUCTION}

The pollution of aqueous solutions (water and waste water) with heavy metals is considered dangerous because of the great toxicity and non-biodegradability. These pollutants can be accumulated through the food chain even at a low concentration rate which is liable to lead to serious problems on aquatic life as well as to animal, plant life and human health ${ }^{1-3}$. Particularly, $\mathrm{Cd}(\mathrm{II})$ is common metal ions found in effluents of a large number of industries ${ }^{4}$, therefore, it is necessary to design processes to effectively minimize the pollution caused by $\mathrm{Cd}$ (II) discharges and to reduce the risks associated with its presence in the environment. While looking for a potential tool to remove the $\mathrm{Cd}(\mathrm{II})$, we have used the phosphogypsum which is a byproduct of commercial production of phosphoric acid. About 5 tons of phosphogypsum are produced for every ton of the phosphoric acid ${ }^{5}$. We can use phosphogypsum to remove some impurities such as $\mathrm{Cd}$ (II) by adsorption which is dangerous for the health of humans, animals and for the environment ${ }^{6}$. The parameters that can influence the adsorption are the contact time, the adsorbate $[\mathrm{Cd}(\mathrm{II})]$ and the adsorbent (phosphogy-psum). The main objective of this research is to determine and to evaluate the effects of these factors using the adsorption isotherms Langmuir, Freundlich and Temkin. Then the chemometrics methods will be used for the modeling and optimizing the adsorption of $\mathrm{Cd}(\mathrm{II})$ on the phosphogypsum by Box-Behnken design experiments.

\section{EXPERIMENTAL}

The phosphogypsum produced during the wet process manufacture of phosphoric acid by attack of tricalcium phosphate by the sulfuric acid, the reaction is:

$$
\mathrm{Ca}_{3}\left(\mathrm{PO}_{4}\right)_{2}+3 \mathrm{H}_{2} \mathrm{SO}_{4}+6 \mathrm{H}_{2} \mathrm{O} \rightarrow 3\left(\mathrm{CaSO}_{4}, 2 \mathrm{H}_{2} \mathrm{O}\right)+2 \mathrm{H}_{3} \mathrm{PO}_{4}
$$

The prepared solution was mechanically stirred at $80^{\circ} \mathrm{C}$. After $1 \mathrm{~h}$ and half of maturation, the solution is filtered hot, to retrieve the first filtrate which is phosphoric acid. Then the phosphogypsum was washed with hot water double distilled and pure acetone. It is finally dried for $24 \mathrm{~h}$ at $80^{\circ} \mathrm{C}$.

Later, a fixed quantity of phosphogypsum was dissolved with a volume of the sample solution containing a fixed concentration of $\mathrm{Cd}(\mathrm{II})$ at a temperature $\mathrm{T}=22{ }^{\circ} \mathrm{C}$ and $\mathrm{pH}$ maintained at 5, 84. And the contact time varied from 0 to $2 \mathrm{~h}$. In the next step, the same work for the varied cadmium concentration was carried out with $0,2-1 \mathrm{~g} / \mathrm{L}$ and the same work for the varied phosphogypsum was carried out with $10-50 \mathrm{~g} / \mathrm{L}$, to find out the effect of these parameters on the adsorption and the removal of $\mathrm{Cd}(\mathrm{II})$, after the solution is filtered and retrieved. The amount of cadmium was analyzed by ICP-AES. 


\section{RESULTS AND DISCUSSION}

Effect of contact time: Fig. 1 shows the influence of the contact time on the adsorption on the phosphogypsum. The analysis of the kinetic curve shows that the adsorption of cadmium on the phosphogypsum is changing rapidly during the first minutes of the reaction. This explains probably that the rate of adsorption decreases in the later stages of the adsorption due to the slow pore diffusion of the solute ion into the bulk of the adsorbent.

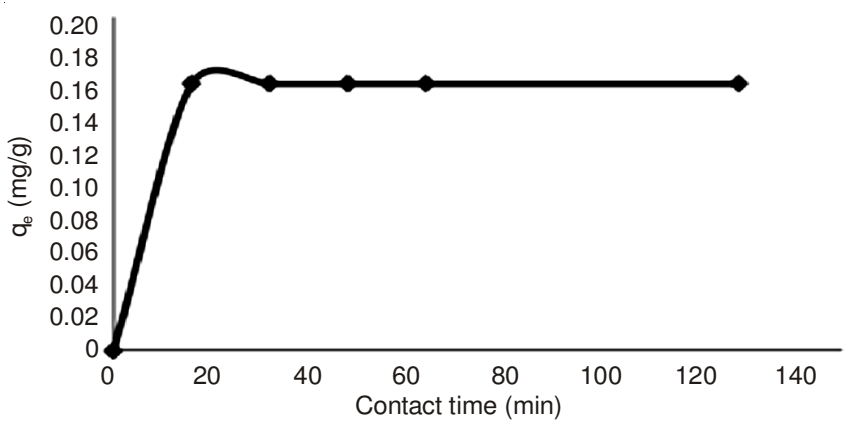

Fig. 1. Effect of the contact time on the adsorption of $\mathrm{Cd}(\mathrm{II})$ on the phosphogypsum, $\left[\mathrm{Cd}^{2+}\right]=1 \mathrm{~g} / \mathrm{L}, \mathrm{V}=50 \mathrm{~mL}, \mathrm{pH}=5,84 ; \mathrm{T}=22{ }^{\circ} \mathrm{C}$

Effect of phosphogypsum concentration: Fig. 2 shows the effect of phosphogypsum concentration on $\mathrm{Cd}(\mathrm{II})$ adsorption. The amount of $\mathrm{Cd}(\mathrm{II})$ adsorbed by unit weight of the adsorbent decreased. The decrease in the adsorbed amount with the increase in adsorbent concentration may result from the electrostatic interactions, interference between binding sites and reduced mixing at higher concentration adsorbent ${ }^{7}$.

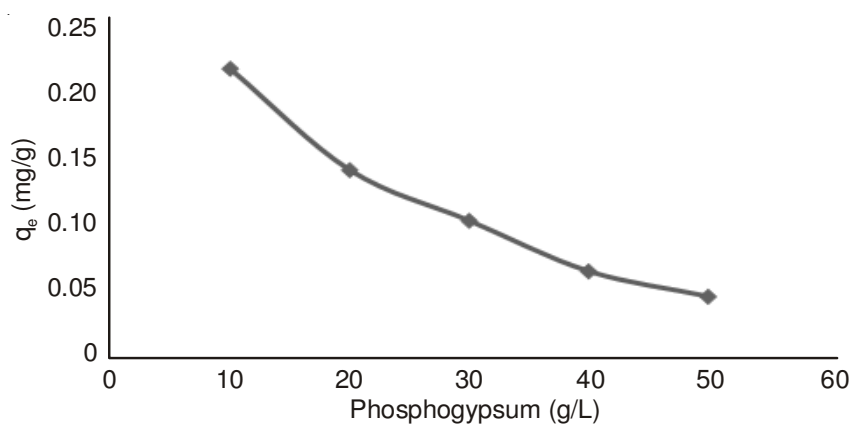

Fig. 2. Effect of phosphogypsum concentration. $\left[\mathrm{Cd}^{2+}\right]=1 \mathrm{~g} / \mathrm{L}, \mathrm{V}=50 \mathrm{~mL}$, $\mathrm{pH}=5,84, \mathrm{~T}=22{ }^{\circ} \mathrm{C}$, Contact time: $60 \mathrm{~min}$

Langmuir, Freundlich and Temkin adsorption isotherms: The Langmuir adsorption isotherm represents the distribution equilibrium of metal ions between the solid and liquid phases ${ }^{8}$. It is valid for monolayer adsorption onto a surface containing a finite number of identified sites. Langmuir proposed the following model $^{9}$ :

$$
\mathrm{q}_{\mathrm{e}}=\frac{\mathrm{b} \cdot \mathrm{q}_{0} \cdot \mathrm{C}_{\mathrm{e}}}{1+\mathrm{b} \cdot \mathrm{C}_{\mathrm{e}}}
$$

The linear isotherm equation is represented as:

$$
\frac{\mathrm{C}_{\mathrm{e}}}{\mathrm{q}_{\mathrm{e}}}=\frac{\mathrm{C}_{\mathrm{e}}}{\mathrm{q}_{0}}+\frac{1}{\mathrm{~b} \cdot \mathrm{q}_{0}}
$$

where:

- $\mathrm{C}_{\mathrm{e}}$ the equilibrium concentration of adsorbate $\left(\mathrm{mg} \mathrm{L}^{-1}\right)$

- $\mathrm{q}_{\mathrm{e}}=$ The amount of metal adsorbed per gram of the adsorbent at equilibrium ( $\mathrm{mg} \mathrm{g}^{-1}$ )

- $\mathrm{q}_{0}=$ Maximum adsorption capacity $\left(\mathrm{mg} \mathrm{g}^{-1}\right)$

- $\mathrm{b}=$ Langmuir isotherm constant $\left(\mathrm{L} \mathrm{mg}^{-1}\right)$

The Freundlich adsorption isotherm ${ }^{10}$ is commonly used to describe the adsorption characteristics of the heterogeneous surface ${ }^{11}$. The proposed equation is: $\mathrm{q}_{\mathrm{e}}=\mathrm{K}_{\mathrm{F}} \mathrm{C}_{\mathrm{e}}^{1 / \mathrm{n}}$

The linear form is: $\log \mathrm{q}_{\mathrm{e}}=\log \mathrm{K}_{\mathrm{F}}+1 / \mathrm{n} \log \mathrm{C}_{\mathrm{e}}$

$\mathrm{K}_{\mathrm{F}}$ and $\mathrm{n}$ are Freundlich constants.

The derivation of the Temkin isotherm assumes that the fall in the heat of adsorption is more linear rather than logarithmic, as implied in the Freundlich equation ${ }^{12}$. The model is given by the following equation ${ }^{13}$ :

$$
\mathrm{q}_{\mathrm{e}}=\left(\mathrm{R}_{\mathrm{T}} / \mathrm{b}_{\mathrm{T}}\right) \ln \left(\mathrm{A}_{\mathrm{T}} \mathrm{C}_{\mathrm{e}}\right)
$$

The linear form is: $\mathrm{q}_{\mathrm{e}}=\mathrm{B} \ln \mathrm{A}_{\mathrm{T}}+\mathrm{B} \ln \mathrm{C}_{\mathrm{e}}$.

- $\mathrm{A}_{\mathrm{T}}=$ Temkin isotherm equilibrium binding constant $\left(\mathrm{L} \mathrm{g}^{-1}\right)$

- $\mathrm{b}_{\mathrm{T}}=$ Temkin isotherm constant

- $\mathrm{R}=$ Universal gas constant $\left(8,314 \mathrm{~J} \mathrm{~mol}^{-1} \mathrm{~K}^{-1}\right)$

- $\mathrm{T}=$ Temperature

- $\mathrm{B}=$ Constant related to heat of sorption $\left(\mathrm{J} \mathrm{mol}^{-1}\right)$.

Figs. 3-5 represent the isotherms adsorption Langmuir, Freundlich and Temkin of $\mathrm{Cd}(\mathrm{II})$ on the phosphogypsum and Table- 1 shows the parameters of these isotherms.

The adsorption of $\mathrm{Cd}(\mathrm{II})$ on the phosphogypsum follows the isotherm of Freundlich. The determination coefficient $\left(\mathrm{R}^{2}\right)$ of the model was 0,936 (Table-1). It indicate that $93,6 \%$ of the variability was explained by the model and it represents the real relationship between the variables under consideration. Note also that $\mathrm{n}=1.61>1$ explains that the adsorption isotherm of $\mathrm{Cd}(\mathrm{II})$ on the phosphogypsum can be chemical.

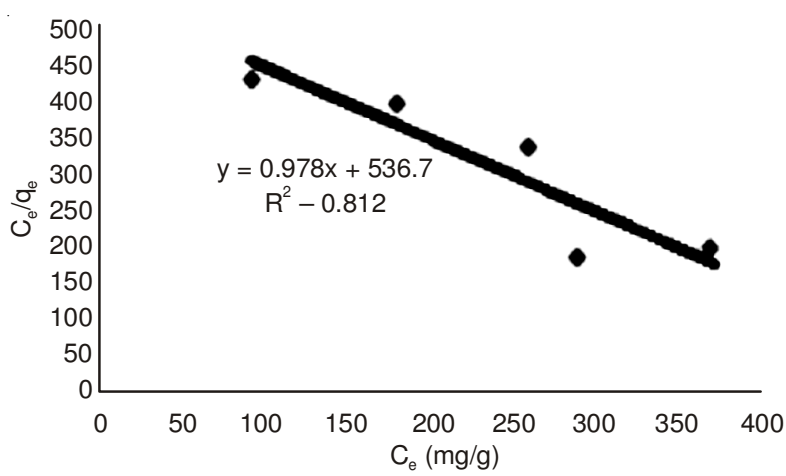

Fig. 3. Langmuir isotherm of $\mathrm{Cd}(\mathrm{II})$ adsorbed on phosphogypsum

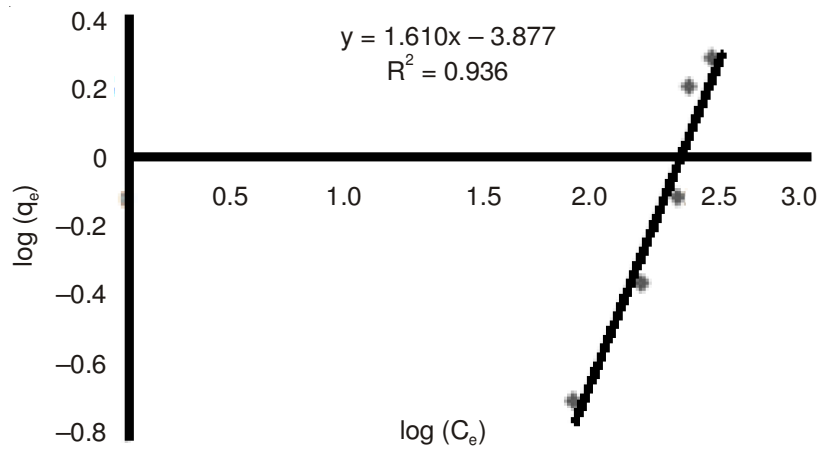

Fig. 4. Freundlich isotherm of Cd(II) adsorbed on phosphogypsum 


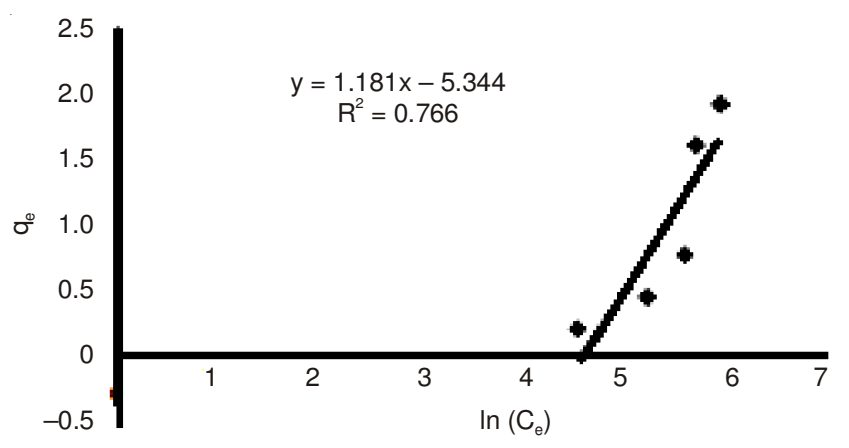

Fig. 5. Temkin isotherm of $\mathrm{Cd}(\mathrm{II})$ adsorbed on phosphogypsum

\begin{tabular}{cccc}
\multicolumn{4}{c}{ TABLE-1 } \\
LANGMUIR, FREUNDLICH AND TEMKIN ISOTHERM \\
CONSTANTS FOR THE ADSORPTION OF Cd(II) \\
FROM AQUEOUS SOLUTIONS \\
\hline \multirow{2}{*}{ Langmuir } & $\mathrm{q}_{0}\left(\mathrm{mg} \mathrm{g}^{-1}\right)$ & $\mathrm{b}\left(\mathrm{L} \mathrm{mg}^{-1}\right)$ & $\mathrm{R}^{2}$ \\
\cline { 2 - 4 } & 1.022 & $1.82 \times 10^{-3}$ & 0.812 \\
\hline \multirow{2}{*}{ Freundlich } & $\mathrm{K}_{\mathrm{F}}$ & $\mathrm{n}$ & $\mathrm{R}^{2}$ \\
\cline { 2 - 4 } & $1.32 \times 10^{-4}$ & 1.610 & 0.936 \\
\hline \multirow{2}{*}{ Temkin } & $\mathrm{A}_{\mathrm{T}}\left(\mathrm{L} \mathrm{g}^{-1}\right)$ & $\mathrm{B}$ & $\mathrm{R}^{2}$ \\
\cline { 2 - 4 } & $1.08 \times 10^{-2}$ & 1.181 & 0.766 \\
\hline
\end{tabular}

Box-Behnken design: Modeling is to define an empirical model that describes the variations of the response $\mathrm{Y}$ as a function of various factors that may affect these changes ${ }^{14-16}$. Our research allowed to identify the factors that affect the amount of cadmium adsorbed (Y) on the phosphogypsum which are: the contact time between the adsorbate and adsorbent, cadmium concentration and phosphogypsum concentration, using Box-Behnken design experiments ${ }^{17,18}$. The entire experimental domain is defined by the coded variables $\mathrm{Xi}$ and natural variables xi which are shown in Table-2. The theoretical equation of the model:

$$
\begin{aligned}
Y= & b_{0}+b_{1} X_{1}+b_{2} X_{2}+b_{3} X_{3}+b_{12} X_{1} X_{2}+b_{13} X_{1} X_{3}+ \\
& b_{23} X_{2} X_{3}+b_{11} X_{1}^{2}+b_{22} X_{2}^{2}+b_{33} X_{3}^{2}
\end{aligned}
$$

where $\mathrm{Y}$ (Amount of cadmium adsorbed) is the predicted response, $X_{1}, X_{2}$ and $X_{3}$ are the independent variables, $b_{0}$ is the offset term, $b_{1}, b_{2}, b_{3}$ are the linear effects and $b_{12}, b_{13}$ and $b_{23}$ are the interaction terms.

\begin{tabular}{ccccc}
\multicolumn{5}{c}{ TABLE-2 } \\
CODED AND REAL LEVELS FOR THREE FACTORS \\
$\begin{array}{ccccc}\text { INVESTIGATED } \\
\text { Coded } \\
\text { variables } \mathrm{X}_{\mathrm{i}}\end{array}$ & $\mathrm{X}_{1}, \mathrm{X}_{2}, \mathrm{X}_{3}$ & -1 & 0 & 1 \\
\hline \multirow{2}{*}{ Natural } & $\mathrm{x}_{1}=[\mathrm{PG}]\left(\mathrm{g} \mathrm{L}^{-1}\right)$ & 10 & 15 & 20 \\
variables $\mathrm{x}_{\mathrm{i}}$ & $\mathrm{x}_{2}=\left[\mathrm{Cd}^{2+}\right]\left(\mathrm{mg} \mathrm{L}^{-1}\right)$ & 100 & 150 & 200 \\
& $\mathrm{X}_{3}=$ Time $(\mathrm{min})$ & 10 & 15 & 20 \\
\hline
\end{tabular}

Table-3 shows the different experiences depending BoxBehnken design for different factors influencing the adsorption of $\mathrm{Cd}(\mathrm{II})$ on the phosphogypsum. Table-4 represents the analysis of variance for the adsorption of $\mathrm{Cd}(\mathrm{II})$ on the phosphogypsum.

\begin{tabular}{ccccc}
\multicolumn{5}{c}{ TABLE-3 } \\
\multicolumn{5}{c}{$\begin{array}{c}\text { EXPERIMENTAL MATRIX OF ADSORPTION } \\
\text { MODEL OF Cd ON PHOSPHOGYPSUM }\end{array}$} \\
\hline $\mathbf{N}^{\circ}$ & $\mathrm{X}_{1}$ & $\mathrm{X}_{2}$ & $\mathrm{X}_{3}$ & $\mathrm{Y}\left(\mathrm{mg} \mathrm{g}^{-1}\right)$ \\
\hline 1 & -1 & -1 & 0 & 0.22 \\
2 & 1 & -1 & 0 & 0.14 \\
3 & -1 & 1 & 0 & 0.10 \\
4 & 1 & 1 & 0 & 0.06 \\
5 & -1 & 0 & -1 & 0.04 \\
6 & 1 & 0 & -1 & 0.21 \\
7 & -1 & 0 & 1 & 0.45 \\
8 & 1 & 0 & 1 & 0.77 \\
9 & 0 & -1 & -1 & 1.60 \\
10 & 0 & 1 & -1 & 1.91 \\
11 & 0 & -1 & 1 & 0.16 \\
12 & 0 & 1 & 1 & 0.16 \\
13 & 0 & 0 & 0 & 0.16 \\
14 & 0 & 0 & 0 & 0.16 \\
15 & 0 & 0 & 0 & 0.16 \\
\hline
\end{tabular}

The equation of the model is $\mathrm{Y}=0.1600+0.0460 \mathrm{X}_{1}+$ $0.0140 \mathrm{X}_{2}-0.2770 \mathrm{X}_{3}+0.0100 \mathrm{X}_{1} \mathrm{X}_{2}+0.0370 \mathrm{X}_{1} \mathrm{X}_{3}-$ $0.0770 \mathrm{X}_{2} \mathrm{X}_{3}-0.310 \mathrm{X}_{1}^{2}+0.2800 \mathrm{X}_{2}^{2}+0.5170 \mathrm{X}_{3}^{2}$

The analysis of variance for the adsorption of $\mathrm{Cd}(\mathrm{II})$ on the phosphogypsum shows that for an estimate of $80 \%$, the model is:

$$
\begin{array}{ccc}
\mathrm{Y}=0.1600+0.0460 \mathrm{X}_{1}+ & 0.0140 \mathrm{X}_{2}+0.0100 \mathrm{X}_{1} \mathrm{X}_{2} \\
( \pm 0.0041) \quad( \pm 0.0020) & ( \pm 0.0006) \quad( \pm 0.0003) \\
+ & 0.0370 \mathrm{X}_{1} \mathrm{X}_{3}-0.0770 \mathrm{X}_{2} \mathrm{X}_{3} \\
& ( \pm 0.0011) & ( \pm 0.0023)
\end{array}
$$

Optimization of the adsorption on the phosphogypsum: In order to optimize the conditions for the removal of $\mathrm{Cd}(\mathrm{II})$ from aqueous solution and to optimize the influential variables on the adsorption, contour plots were used to investigate the effect of all the factors on the responses (Figs. 6-8).

The analysis of the plots shows the quantity of $\mathrm{Cd}(\mathrm{II})$ adsorbed on phosphogypsum was low (Figs. 6 and 7) than the amount of cadmium adsorbed in Fig. 8.

It is concluded that the optimum is $125 \mathrm{mg} / \mathrm{L}$ of cadmium on $15 \mathrm{~g} / \mathrm{L}$ of phosphogypsum (Fig. 8).

\section{Conclusion}

In this paper, investigation of the equilibrium adsorption was carried out at $22{ }^{\circ} \mathrm{C}$ and $\mathrm{pH}=5,84$. Other physicochemical parameters were determined and three adsorption isotherm models were studied.

TABLE-4

ANALYSIS OF VARIANCE FOR THE ADSORPTION OF Cd(II) ON THE PHOSPHOGYPSUM

\begin{tabular}{cccccc}
\hline Source & Nparm & DF & Sum of squares & F Ratio & Prob $>$ F \\
\hline$X_{1}$ & 1 & 1 & 0.0171 & 0.0382 & 0.8528 \\
$X_{2}$ & 1 & 1 & 0.0015 & 0.0034 & 0.9559 \\
$X_{3}$ & 1 & 1 & 0.6160 & 1.3737 & 0.2940 \\
$X_{1} X_{1}$ & 1 & 1 & 0.3548 & 0.7912 & 0.4145 \\
$X_{2} X_{1}$ & 1 & 1 & 0.0004 & 0.0009 & 0.9773 \\
$X_{2} X_{2}$ & 1 & 1 & 0.2895 & 0.6455 & 0.4582 \\
$X_{3} X_{1}$ & 1 & 1 & 0.0056 & 0.0125 & 0.9152 \\
$X_{3} X_{2}$ & 1 & 1 & 0.0240 & 0.0536 & 0.8261 \\
$X_{3} X_{3}$ & 1 & 1 & 0.9888 & 2.2050 & 0.1977 \\
\hline
\end{tabular}




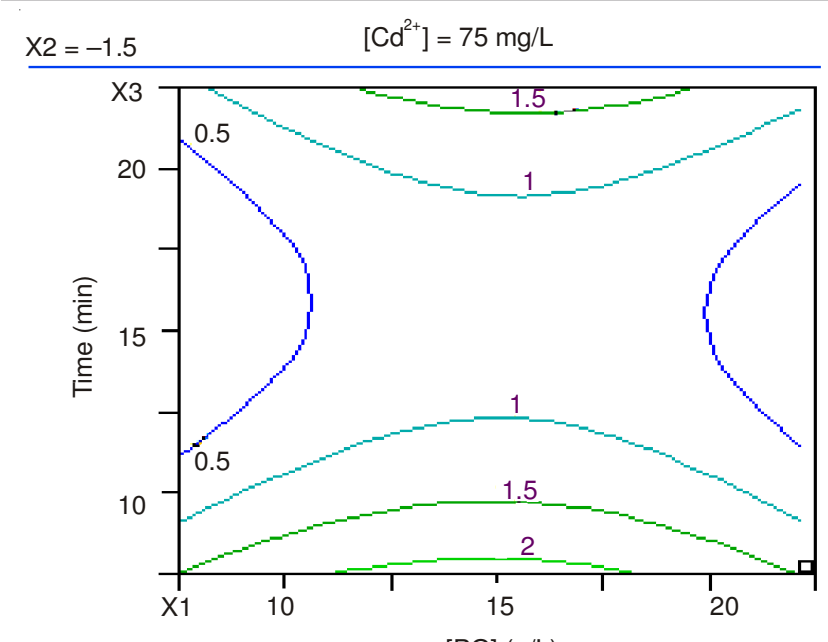

$[P G](g / L)$

Fig. 6. Effect of the interaction between contact time and phosphogypsum

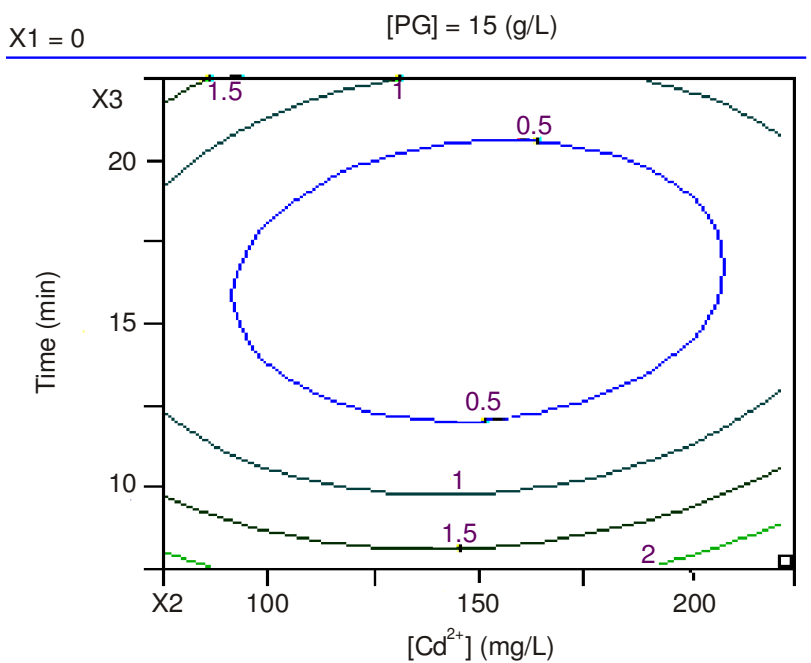

Fig. 7. Effect of the interaction between contact time and concentration of $\mathrm{Cd}(\mathrm{II})$

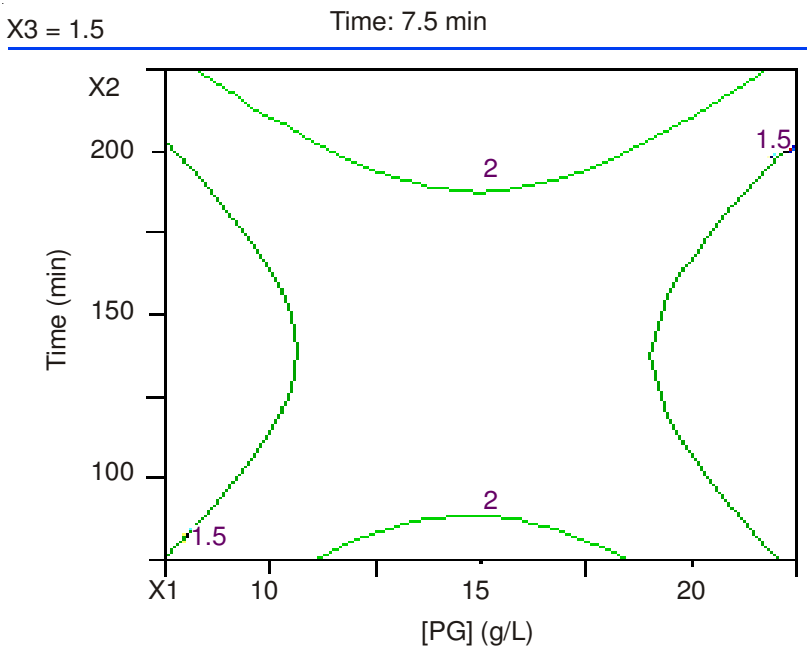

Fig. 8. Effect of the interaction between concentration of $\mathrm{Cd}(\mathrm{II})$ and phosphogypsum
This study showed that the adsorption follows the Freundlich adsorption isotherm and the model equation by Box-Behnken design with an estimated $80 \%$ is:

$$
\begin{array}{ccc}
\mathrm{Y}=0.1600+0.0460 \mathrm{X}_{1}+ & 0.0140 \mathrm{X}_{2}+0.0100 \mathrm{X}_{1} \mathrm{X}_{2} \\
( \pm 0.0041) \quad( \pm 0.0020) & ( \pm 0.0006) \quad( \pm 0.0003) \\
+ & 0.0370 \mathrm{X}_{1} \mathrm{X}_{3}-0.0770 \mathrm{X}_{2} \mathrm{X}_{3} \\
& ( \pm 0.0011) & ( \pm 0.0023)
\end{array}
$$

The optimum is $125 \mathrm{mg} / \mathrm{L}$ from concentration of $\mathrm{Cd}(\mathrm{II})$ in $15 \mathrm{~g} / \mathrm{L}$ for phosphogypsum.

It could be concluded that the phosphogypsum could be considered as a good material and alternative approach for aqueous solutions treatments polluted by $\mathrm{Cd}(\mathrm{II})$, a potential and active sorbent for removal of cadmium ions from industrial waste water remediation and a way of the removal of other impurities such as zinc ${ }^{19}$ and copper ${ }^{20}$.

\section{REFERENCES}

1. M.R. Mehrasbi and Z.F. Kia, Iran. J. Health Environ., 1, 57 (2008).

2. M.S. Rahman and M.R. Islam, Chem. Eng. J., 149, 273 (2009).

3. N. Boldizsar, M. Andrada, I. Cerasella, B. Silvia, S.D. Luminita and M. Cornelia, Acta Chim. Slov., 60, 263 (2013).

4. R. Bchitou, M. Hamad, J.L. Lacout and M. Ferhat, Phosphorus Sulfur Silicon Relat. Elem., 139, 147 (1998).

5. D. Chafik, R. Bchitou and A. Bouhaouss, Aust. J. Basic Appl. Sci., 7, 254 (2013)

6. R.J.E. Martins, R. Pardo and R.A.R. Boaventura, Water Res., 38, 693 (2004).

7. E. Fourest and J. Roux, Appl. Microbiol. Biotechnol., 37, 399 (1992).

8. A.O. Dada, A.P. Olalekan, A.M. Olatunya and O. Dada, IOSR J. Appl. Chem., 3, 38 (2012).

9. I. Langmuir, J. Am. Chem. Soc., 40, 1361 (1918).

10. H. Freundlich, Colloid and Capillary Chemistry, Methuen, London (1926).

11. N.D. Hutson and R.T. Yang, Adsorption, 3, 189 (1997).

12. C. Aharoni and M. Ungarish, J. Chem. Soc., Faraday Trans. I, 73, 456 (1977).

13. M.J. Temkin and V. Pyzhev, Acta. Physicochim. URSS, 12, 217 (1940).

14. R. Bchitou, M. Hamad, J.L. Lacout and M. Ferhat, Phosphorus Sulfur Silicon Relat. Elem., 119, 193 (1996).

15. N. Aslan and Y. Cebeci, Fuel, 86, 90 (2007).

16. D. Chafik, R. Bchitou and A. Bouhaouss, Phosphorus Sulfur Silicon Rel. Elem., 189, 353 (2014).

17. G.E.P. Box and D.W. Behnken, Technometrics, 2, 455 (1960).

18. G.E.P. Box and N.R. Draper, Biometrika, 50, 335 (1963).

19. D. Chafik, R. Bchitou and A. Bouhaouss, Aust. J. Basic Appl. Sci., 8, 331 (2014).

20. D. Chafik, R. Bchitou, A. Bouhaouss, J. Mater. Environ. Sci., 5, 1605 (2014). 